\title{
A Survey into the Cultural Background of Emerson's Educational Thought
}

Jing Yang1*, Yang Yiyi2

${ }^{1}$ Department of English, Foreign Languages College, Nanjing Normal University, 210097, Nanjing, China, ${ }^{2}$ Department of English, Zhongbei College, Nanjing Normal University, 210097, Nanjing, China

Corresponding Author: Jing Yang, E-mail: yangjing@njnu.edu.cn

\section{ARTICLE INFO}

Article history

Received: October 18, 2019

Accepted: December 12, 2019

Published: February 29, 2020

Volume: 11 Issue: 1

Advance access: February 2020

Conflicts of interest: None

Funding: None

\begin{abstract}
As an avid advocator of education reform in the 1850s, Emerson was long neglected in the history of American educational thought. This paper, through the investigation from four aspects, namely the Transcendental Educational Thought, the Puritanical Educational Thought, the Romantic Educational Thought, and the Confucian's Educational Thought, attempts to figure out the cultural background of Emerson's education thought, tries to work out the connections between his ideas and his contemporaries, such as Thoreau, Fuller, and Alcott, and points out the significant role it plays in the history of American education thought up to day.
\end{abstract}

\section{Key words:}

Emerson,

Transcendentalism,

Confucianism,

Puritanism,

Educational Thought

\section{INTRODUCTION}

Ever since President Thomas Jefferson advocated the public education movements in the $1800 \mathrm{~s}$, New England has led the nation in its response. After the 1830s and 1840s, Horace Mann, a pioneer of American educational reform, established the common schools in Massachusetts, which relied on public taxes and was open to all the people without denomination. Other education and training institutions, such as academies, public schools and workshops, have sprung up and created new educational atmosphere in England. Ralph Waldo Emerson was a great advocate of this movement. Martin Bickman, a prominent contemporary American scholar, argued that Emerson, along with Bronson Alcott, Henry David Thoreau and others, created a new education tradition of active learning in American education, which was inherited by John Dewey (Bickman,2003).

However, as an avid advocator of education reform in the 1850s, Emerson was long neglected in the history of American educational thought. This paper, through the investigation from four aspects, namely the Transcendental Educational Thought, the Puritanical Educational Thought, the Romantic Educational Thought, and the Confucian's Educational Thought, attempts to figure out the cultural background of Emerson's education thought, tries to work out the connections between his ideas and his contemporaries, such as Thoreau, Fuller, and Alcott, and points out the significant role it plays in the history of American education thought up to day.

\section{TRANSCENDENTAL EDUCATIONAL THOUGHT}

Transcendentalists advocate that people should have a higher and broader spiritual pursuit on the basis of material life. In his speech "The Transcendentalist," Emerson once said, "an improvement in dress, or in dentistry, a new house or a larger business...soon these improvements and mechanical inventions will be superseded (Porte, 1993), but one's spiritual pursuit will stay, which is heavily linked with education.

As we all know, Emerson's thoughts are very complicated. His Transcendentalism philosophy is a mixture of German classical philosophy, Anglo-French Romanticism and Oriental Mysticism. He has persevered in academic research all the year round, while his personal life can also be called a moral model. Emerson himself, who has been followed by generations of young people, deserved to be among the "Representative Men", who he praised for changing the course of history. Through his effort, the mysterious Transcendentalism philosophy and the American pragmatism spirit are amaz- 
ingly blended together, which to a large extent represents the so-called "The American Mind" by H. S. Commager.

As for the origin and ideological background of Transcendentalism, apart from its religious background, there are three main influences: one is Neo-Platonism, a mystical philosophy popular in ancient Rome from the 3rd to 6th centuries A.D. This philosophy emphasizes the supremacy of spirit and advocates a pure life of pursuing the best and the most beautiful. It is a kind of inheritance and development of the ancient Greek Philosophy of Plato. The second is German idealist philosophy, especially Kant's "apriorism": systematic knowledge is subjective, transcendental, and the essence of the world is unknown; the third is Oriental mysticism, especially Hinduism, which promotes the self of individual soul through practice. In other words, human beings are combined with the soul of the universe, that is, heaven, so as to reach the highest state of "the unity of heaven and man" (Zhikang, 1998).

Like Montaigne, Plato is one of Emerson's favorite philosophers. They all firmly believe that the progress and development of any society cannot be separated from education-Plato put forward this view in the fourth century B.C., which has become the consensus of people in modern society. In Plato's view, in order to realize the highest idea and achieve the goal of the ideal country, we should (or can only) realize it through education. No matter in terms of cultivating their respective skills, abilities, virtues, or in terms of exploring the characteristics of their respective souls, education cannot be ignored (Tianyi, 1990).

Influenced by his philosophy of objective idealism, Plato's educational thought is based on mystical "epistemology". Knowledge is not a recognition of the material world, but a memory of the ideological world. Therefore, Plato is convinced that the process of learning is the process of restoring our inherent knowledge. Plato's influence was obvious to Emerson, when he advocated that learning from nature because "it is the memory of the human mind".

The Transcendentalist view of education, in essence, is to believe that everyone is a genius with infinite potential in his body. The purpose of education is to stimulate this potential, so that everyone has the opportunity to realize personal value. In Emerson's opinion, self-education is the way to realize it.

\section{PURITANICAL EDUCATIONAL THOUGHT}

Born into a clerical family, Emerson was deeply affected by puritanism from the day he came to the world. To a large extent, he couldn't make such great achievements in literature and thought without puritan educational background since his early years.

Even in the most blooming years of Renaissance, those humanists of different countries were cautious and careful in fear of touching the foundation of church authority. However, Reformation intensely broke out from the inner of the church almost at the same time, which exerted a profound effect on the politics, economy and culture of the countries in western Europe and even those of the whole world. All sects of Protestantism led by Martin Luther and John Calvin attached great importance to education, because its popularity (especially the reading and widespread of Holy Bible) not only can expand the influence of the creed, but also can attract more followers and hence win the decisive victory of the religious war.

Holding the same opinion with Genevan reformers, the puritans landing on American continent also hoped to realize their dream, transforming society into a new one, through education. 1636 saw the establishment of Harvard College, which provided students with European academic ideal developed by Americans and prepared elementary conditions for those aspired to engage three traditional occupations: doctors, lawyers and priests. Puritans believed that the values taught in society should be the same as that in school. However, this outlook faded out as capitalism emerged and developed in North America. An increasing number of puritans sent their children to private schools where miscellaneous practical skills are taught ranging from commerce to shipbuilding. In Franklin's view, talents cultivated under this new type of educational thought was conducive to developing capitalism.

Benjamin Franklin's success was built up from self-teaching, and his life outlook, in Vernon Louis Parrington's eye, “doesn't focus on abstract reasoning, but social life improvement" (Louis Parrington, 2002). Perhaps his literary talent could be overestimated, while his influence on Americans' thought and spirit, as an example and prototype, could never be overestimated. He summarized a set of pragmatism philosophy through his personal experience. "In his pragmatism philosophy, reason and enterprise loyally serve for progress," (Louis Parrington, 2002) while both reason and enterprise have much to do with education. In On the Recommendations for Youth Education in Pennsylvania, Franklin suggested that schools should teach in English and modern foreign language should be introduced in the secondary school and be attached the same importance as classic languages such as Greek and Latin (Xianglin, 1992).

Based on these educational thoughts, Franklin proposed a new type of school (Academy), in order to teach useful courses in place of classic Latin grammar school. This kind of academy became the most popular educational institution in the colonies before long, terminating the era of Latin grammar school, which dominated Britain and European continent for a long time (Bogues, 1998).

Therefore, we should say that the foundation of Academy deeply affected the modern education history of America. It was the first important step of American secondary education that helped Latin grammar school transform into contemporary high school, which both inherited the theory-focused tradition of Latin grammar school, and improved the status of practical courses, building up a bridge between Latin grammar school and public school (Xianglin, 1992).

As the first American to be highly complimented on European continent, Franklin was diligent, self-excited, positive, out-going, democratic and patriotic. These virtues were well exhibited in Emerson half century later. Actually, whether for Emerson or Franklin, puritan ethics and morals were taken as top value pursing for a lifetime. 
It should be noted that Academy established by Franklin was an American expression in the spirit of John Locke's educational thought. Similar to his predecessors, Locke also regarded education as a key in political entity to improving individual and changing society. His assumption of tabula rasa exaggerated the function of education to a supreme extent. In his Some Thoughts Concerning Education (1693), as for the purpose and function of education, he claimed that "...of all the men we meet with, nine parts of ten are what they are, good or evil, useful or not, by their education. It is education which makes the great difference in mankind" (Locke, 1963).

The best way to implement such kind of "gentleman education", in Locke's consistent view, was to practice family education. It is under such a one-to-one education method that one can tap into his uttermost potential. Emerson totally agreed with Locke as to this point. Horace Mann, Emerson's contemporary educationist, proposed to establish Common School, while Emerson was strongly against his theory of "education science". In Mann's ideal thought, school should be developed into a unified system where everyone can walk at the same pace and no one has the right to act differently, which was strongly contradicted with Emerson's individualism. To his sadness, when he saw adults "impose their own opinion, thinking mode and lifestyle on their children", Emerson asked, "Couldn't we allow people to live and enjoy their life at their own will?" (Bogues, 1998). Or, in Henry David Thoreau's words, America doesn't need any "common school", but does need "uncommon school".

\section{ROMANTIC EDUCATIONAL THOUGHT}

Jean-Jacques Rousseau (1712-1778) was the one who made a whole set of educational ideas among the representative figures in the 18th century's Romantic Movement and also had a great impact. His educational novel Emile became a sensation once published and it is still popular with readers. In this novel that embodies his educational thoughts, Rousseau not only criticized the various drawbacks of the old-fashioned education system, like his predecessor Francois Rabelais (1495-1553) did, but also first proposed the idea of natural education, from which much of Emerson's view of "learning" came.

In addition, in the era of Emerson's life, Germanic educational standard led the way in the world. The pedagogy system which was established by Herbart and Frobel based on German classical philosophy, has made an impact on the education in Europe, America and even the rest of the world. Meanwhile, Kant's educational ideology, which represents the highest achievement of German classical philosophy, has also had a tremendous impact on the world.

Kant's educational thoughts influenced not only Johann Gottlieb Fichte (1762-1814), who were contemporary with him, but also Johan Heinrich Pestalozzi (1746-1827), the famous Swiss educator. Therefore, it is no surprise that Emerson, who was obsessed with German classical philosophy and culture, would draw on the essence from it. Emerson defines education as the extension of human nature from the inner world to the external world, or the natural growth, which is a refurbished version of the above Kant's educational thoughts (Helm, 1992).

In addition to moral education, Kant's On Education deliberately argues about the importance of physical education (PE) in the second chapter next to the preface. Like Locke, he is convinced that to promote the natural growth of the body and the physical strength, which is the goal of PE, is closely linked with the level of mental ability and intelligence. Only through the seamless combination of the two can we truly cultivate a "perfect man" with healthy and coordinated development of the body and spirit.

It is a natural thing for Emerson, a master of American intellectual history and even the history of Western culture, to extensively collect and organize Western excellent culture and intellectual heritage, making it self-contained and passed on to future generations. Yet it is worthy of being noticed that in Emerson's richly conceived ideology, the Oriental cultures, especially the Confucian ideas and doctrines, can be found in his speeches and writings.

\section{CONFUCIAN'S EDUCATION THOUGHT}

In her book Emerson and China-Reflections on Individualism, Qian Mansu summarized the influence of Confucius, the great Chinese thinker and educator, on Emerson's educational thoughts. First of all, with regard to the purpose of education, Confucius and Emerson both believe that the purpose of education is to cultivate a well-rounded person-a gentleman, who can "be interested in classics, in compliance with rituals and engaged in the enjoyable" and eventually become a complete people, not just an accountant, an engineer, or someone who has mastered some living skills. Confucius's view that "the gentleman should not live like a machine" resonates with Emerson's heart who advocates the natural development of nature.

Secondly, in terms of teaching methods, Emerson and Confucius believe in the endowment of individuals. Therefore, it is necessary to teach each student according to their different characteristics. Among the three thousand students of Confucius, there are seventy-two sages, officials, businessmen, scholars, and persons of all walks of life, all of whom can be known as "somebody" at that time. This example shows the success of this teaching method.

Their ideas are also consistent in inspiring students to be active and creative. Confucius encourages students to think independently and ask questions, and to work with him to explore the truth together. He said that "Once there is a chance to do humane practice, students should actively grasp it and do not wait for the teacher to practice it first". Likewise, Emerson advocates that if a student has the courage to speak out about the teacher's mistakes in class, the teacher should not hesitate to hug him to show the award.

Thirdly, in the relationship between learning and using, Confucius always emphasizes that the purpose of learning is to use, which is "the gentleman learns to use his or her own way" or "learn to use it". And Emerson also believed that "life is our dictionary" - only in the practice of life can knowledge from the book be transformed into something that truly belongs to oneself, and it can better guide future 
practical actions. They all attach importance to the acquisition of ancient cultural heritage. Confucius claims himself to be a man interested in ancient culture and dedicated to exploring knowledge and truth. Similarly, Emerson is also familiar with ancient Greek and Roman classics like Homer, and can obtain them off-handedly. For them, learning is not only a means of earning a living, but also a purpose and a way of life, and enables them to be creatively adapted to the new environment. That is what Confucius says - "If a man keeps reviewing his old knowledge, he may find something new and become a master in his field".

Finally, in the relationship between learning and thinking, Confucius believes that thinking should be the result of learning. Only by continuous learning can one understand his own ignorance and thus deepen his own thoughts. He said: "I used to give up eating all day, stay up all night, and think about problems, but it didn't help. So I might as well study." Or, like another Confucian master-Xunzi said: "I've tried to think about a question all day long, only to find that I can acquire more knowledge through learning." Conversely, thinking has a positive effect on learning. The relationship between the two should be complementary. In his words, that is "Learning without thought is labor lost, while thought without learning is perilous."

\section{CONCLUSION}

As an avid advocator of education reform in the 1850 s, Emerson was long neglected in the history of American educational thought. This paper, through the investigation from four aspects, namely the Transcendental Educational Thought, the Puritanical Educational Thought, the Romantic Educational Thought, and the Confucian's Educational Thought, attempts to figure out the cultural background of Emerson's education thought, tries to work out the connections between his ideas and his contemporaries, such as Thoreau, Fuller, and Alcott, and points out the significant role it plays in the history of American education thought up to day.

The similarity between Emerson and Confucius is very striking and worth particular noting. Like the Saint in China, Emerson also believes that scholars' purpose of study is to be a person who can think, a "man thinking", rather than a "book-worm" who does not know much about life and the world. As Qian Mansu sums up, "Emerson has been quoting hundreds of quotations from Confucius. We are surprised to find that there are so many common ideas between Emerson's thoughts and Confucianism in morality, humanity, self-discipline, and study." The ancient Chinese wisdom and cultural heritage represented by Confucius is indeed praised as "immortal spiritual treasure", and "Emerson, relying on his transcendental intuition, revealed the best part of it." Of course, these ancient wisdom and classic doctrines, selected and quoted by Emerson, will undoubtedly express Emerson's own educational thoughts in a more clear and concise way. Meanwhile, the ancient wisdom itself has been endowed with a certain modern color. In this sense, Emerson is hailed as "Saint of Concord," which is obviously well deserved.

\section{REFERENCES}

Charles Bogues, The Origin of American Thought, translated by Fu Hongling, Taiyuan: Shanxi People Press, 1988, p.108

Charles Bogues, The Origin of American Thought, translated by Fu Hongling, Taiyuan: Shanxi People Press, 1988, p.146.

Charles Bogues, The Origin of American Thought, translated by Fu Hongling, Taiyuan: Shanxi People Press, 1988, p. 146.

Joel Porte ed., Emerson: Essays and Lectures, translated by Zhao Yifan et al, Beijing: SDX Joint Publishing Company, 1993, p.227.

John Locke, Some Thoughts Concerning Education, translated by Fu Rengan, Beijing: People's Education Press, 1963, p.4.

Martin Bickman, Minding American Education: Reclaiming the Tradition of Active Learning, New York: Teachers College Press, 2003, p.2.

Pert P. Helm, "Emerson Agonists: Education as Struggle and Process," in Educational Theory, 1992(2), pp.165-180.

Shi Zhikang, ed., An Outline of Backgrounds of American Literature, Shanghai: Shanghai Foreign Language Education Press, 1998, pp.70-71.

Vernon Louis Parrington, Main Currents in American Thought, translated by Chen Yongguo et al, Changchun: Jilin People's Press, 2002, p.151.

Vernon Louis Parrington, Main Currents in American Thought, translated by Chen Yongguo et al, Changchun: Jilin People's Press, 2002, p.159.

Wang Tianyi, ed., History of Foreign Education, Beijing: Beijing Normal University Press,1993, p.45.

Zhao Xianglin, Commentary on Foreign Educators (2), Shanghai: Shanghai Educational Publishing House, 1992 , p.354.

Zhao Xianglin, Commentary on Foreign Educators (2), Shanghai: Shanghai Educational Publishing House, 1992, p.361 